\title{
SCANDINAVIAN JOURNAL
}

\author{
$\mathrm{OF}$ \\ Plastic and
}

Reconstructive

Surgery

Chief Editor: Bengt Johanson, Göteborg

Co-Editor: Oddvar EIKEN. Malmö

Assistant Editor: JAN LILJA, Göteborg

Editorial Board:

P. Fogh-Andersen

Copenhagen

Halfdan Schuelderup

Bergen
LARS HAKELILI;

Uppsala

AARNE RINTALA

Helsinki

\section{Vol. 201986}


No. 1

Bengt Nylén, M.D. In Memoriam 1

P. Tessier and D. Hemmy (Suresnes, France and Milwaukee, USA): Three dimensional imaging in medicine. A critique by surgeons 3

D. B. Apfelberg (Palo Alto, USA): Summary of argon laser usage in plastic surgery 13

D. B. Apfelberg (Palo Alto, USA): Summary of carbon dioxide laser usage in plastic surgery 19

W. T. Theuvenet, G. F. Koeyers and M. H. M. Borghouts (Nijmegen, The Netherlands): Thermographic assessment of perforating arteries. A preoperative screening method for fasciocutaneous and musculocutaneous flaps 25

K. Inoue and K. Matsumoto (Hamamatsu, Japan): Quantification of texture match of the skin graft: Function and morphology of the stratum corneum 31

J.-P. A. Nicolai, M. Y. Bos and B. G. A. ter Haar (Arnhem and Nijmegen, The Netherlands): Hereditary congenital facial paralysis 37

A. Massei (Pisa, Italy): Reconstruction of cleft maxilla with periosteoplasty 41

A. Rintala, E. Marttinen, S.-L. Rantala and I. Kaitila (Helsinki, Finland): Cleft palate in diastrophic dysplasia. Morphology, results of treatment and complications 45 $H$. Holmström (Göteborg, Sweden): The Abbe flap converted to an island flap 51

M. Lejour, J. Duchateau and A. Potaznik (Brussels, Belgium): Routine reinsertion of the hump in rhinoplasty 55 $R$. Gumener, D. Montandon, F. Marty and A. Zbrodowski (Geneva, Switzerland): The subcutaneous tissue flap and the misconception on fasciocutaneous flaps 61

F. V. Nicolle (London, United Kingdom): Secondary rhinoplasty of the nasal tip and columella. The choice of cartilage grafts 67

D. E. Tolhurst (Rotterdam, The Netherlands): Clinical experience and complications with fasciocutaneous flaps 75

Y. Maruyama, K. Onishi and Y. Iwahira (Tokyo, Japan): Reconstructing chest walls with vertical abdominal fasciocutaneous flaps 79

S. Teich-Alasia, G. Ambroggio, E. Oberto, V. Cerutti and A. Perla (Torino, Italy): A subscapular-pubic fascio-cutaneous flap for reconstruction of the chest wall following excision to the extent of near inoperability 85

P. Santi, P. Berrino, A. Galli, C. Quondamcarlo and $M$. L. Rainero (Genova, Italy): Anterior transposition of the latissimus dorsi muscle through minimal incisions 89

$N$. Bricout and P. Banzet (Paris, France): Rectus abdominis myocutaneous flap of the lower type in breast reconstruction 93

A. Scrocca and G. Petrella (Napoli, Italy): Breast reconstruction according to pTNM: Our experience 97

L. Meyer and A. Ringberg (Lund and Malmö, Sweden): A prospective study of psychiatric and psychosocial sequelae of bilateral subcutaneous mastectomy 101
L. P. Weinstein, D. Kovachev and T. Chaglassian (New York, USA): Abdominal wall reconstruction 109

D. Dioguardi and M. Pascone (Bari, Italy): Dermal-fat flaps in the treatment of large post-incisional hernias ("Cross-over flap" technique) 115

$H$. Kjeldsen and B. N. Gregersen (Århus, Denmark): Giant incisional hernias closed with polypropylene mesh 119

M. Pers, K. Snorrason and I. M. Nielsen (Copenhagen, Denmark): Primary results following surgical treatment of pressure sores 123

H. Reichert (Stuttgart, West Germany): Surgical treatment of pressure sores in paraplegics and possible prevention of their recurrence 125

C. Kauer and G. Sonsino (Berck, France): The need for skin and muscle saving techniques in the repair of decubitus ulcers. A case report 129

M. C. Ferreira, G. Gabbianelli, N. Alonso and C. Fontana (Sao Paulo, Brasil): The distal pedicle fascia flap of the leg 133

H. Hammer, I. Bugyi and P. R. Zellner (LudwigshafenOggersheim, West Germany): Soft tissue reconstruction of the anterior surface of the lower leg in burn patients using a free latissimus dorsi muscle flap 137

R. G. Baumeister, S. Siuda, H. Bohmert and E. Moser (München, West Germany): A microsurgical method for reconstruction of interrupted lymphatic pathways: Autologous lymph-vessel transplantation for treatment of lymphedemas 141

F. Mussinelli, A. Carù and T. L. Cipollini (Milano, Italy): Trends in conservative clitoroplasty 147

A. Berger (Hannover, West Germany): Reconstruction of the thenar muscles by microsurgery 153

Announcements 157

No. 2

L. F. Solheim, H. Rönningen, E. Barth and N. Langeland (Oslo, Norway): Effects of acetylsalicylic acid and naproxen on the mechanical and biochemical properties of intact skin in rats 161

L. Wetter, M. S. Ågren, G. Hallmans, I. Tengrup and F. Rank (Umeå, Lund and Malmö, Sweden): Effects of zinc oxide in an occlusive, adhesive dressing on granulation tissue formation 165

P. Thomsen, L. M. Bjursten and L. E. Ericson (Göteborg, Sweden): Implants in the abdominal wall of the rat 173 T. Lähteenmäki (Helsinki, Finland): The regeneration of adrenergic nerves in a free microvascular groin flap in the rat 183

I. Blomgren and H. Holmström (Göteborg, Sweden): Anterior levator resection in congenital genuine blepharoptosis 189

H. Holmström and I. Blomgren (Göteborg, Sweden): Simple adaptation of Müller's muscle to the tarsal plate in congenital blepharoptosis. A preliminary report 197 C. Lauritzen, B. Vällfors and J. Lilja (Göteborg, Sweden): Facial disassembly for tumor resection 201 
C. G. Hagert, P. I. Brånemark, T. Albrektsson, K. G. Strid and L. Irstam (Göteborg, Sweden): Metacarpophalangeal joint replacement with osseointegrated endoprostheses 207

J. Holmberg and L. Ekerot (Malmö, Sweden): The free scapular flap. An alternative to conventional flaps on the upper extremity 219

L. Ekerot, K. Jonsson and L. E. Necking (Malmö, Sweden): Wrist denervation and compression of the lunate in Kienböck's disease 225

L. E. Necking and $O$. Eiken (Malmö, Sweden): ECRLstrip plasty for metacarpal base fixation after excision of the trapezium 229

\section{Case Reports}

C. J. Edeling, K. Snorrason and S. Medgyesi (Copenhagen, Denmark): An atypical case of lupus miliaris faciei simulating dermoid cyst: diagnostic and therapeutic difficulties. Case report 235

$O$. Engkvist and $F$. af Ekenstam (Uppsala, Sweden): Closed dislocation of the scaphoid. A case report and review of the literature 239

O. Engkvist (Uppsala, Sweden): The effect of regional intravenous guanethidine block in acute frostbite. Case report 243

Announcements 247

No. 3

Atso Soivio. In memoriam 249

$B$. Widenfalk, O. Engkvist, L. Ohlsén and K. Segerström (Uppsala, Sweden): Perichondrial arthroplasty using fibrin glue and early mobilization. An experimental study 251

L. Ohlsén and U. Nordin (Uppsala and Stockholm, Sweden): Experimental laryngeal reconstruction with preformed composite graft 259

A. J. Radek (Lodz, Poland): Blood supply of transected rabbit peripheral nerve after end-to-end suture or autogenous grafting. A microangiographic study 273

G. Lundborg, L. B. Dahlin, N. Danielsen and A. K. Nachemson (Lund and Göteborg, Sweden): Tissue specificity in nerve regeneration 279

J. Holmberg, L. Ekerot and S. Sälgeback (Malmö, Sweden): Flap coverage for post-traumatic nerve pain in the arm 285

L.-A․ Broström, A. Stark and G. Svartengren (Stockholm, Sweden): Non-union of the scaphoid treated with styloidectomy and compression screw fixation 289

L. Ekerot, J. Holmberg and I. Niechajev (Malmö, Sweden): Thumb replantation or not? 293

H. Jousimies-Somer, R. Grénman and A. Rintala (Helsin$\mathrm{ki}$, Finland): Bacteriological investigation of secretory otitis media in children with cleft palate 297

R. Källén, A. Broomé, A. Mühlow and N. Forsby (Helsingborg, Sweden): Reduction mammoplasty: Results of preoperative mammography and patient inquiry 303

\section{Case Reports}

F. N. Abu Jamra, M. Massad and R. C. Musharafieh (Beirut, Lebanon): Reconstruction of shoulder and arm defects using the latissimus dorsi myocutaneous flap. A report of five cases 307

H. Holmström, M. Suurküla and C. Lossing (Göteborg, Sweden): Absent latissimus dorsi muscle and anhidrotic axilla in Poland's syndrome. Case report 313

I. Fogdestam and J. Lilja (Göteborg, Sweden): Microsurgical replantation of a total scalp avulsion. Case report 319

O. P. Jakobsson and J. Bergh (Uppsala, Sweden): Acral lentiginous malignant melanoma. Case Report 328

I. Blomgren, J. Lilja, C. Lauritzen and B. Magnusson (Göteborg, Sweden): Multiple craniofacial surgical interventions during 25 years of follow-up in a case of giant fibrous dysplasia. Case report 327

$O$. J. Einarsson and M. Pers (Copenhagen, Denmark): Streptococcal gangrene of the eyelids. Case reports 331

Announcements 337 
LIST OF AUTHORS

For $\AA$ and $\ddot{A}$ see $A$, for $O ̈$ see $O$
Abu Jamra, F. N. 307

Ågren, M. S. 165

Albrektsson, T. 207

Alonso, N. 133

Ambroggio, G. 85

Apfelberg, D. B. 13, 19

Banzet, P. 93

Barth, E. 161

Baumeister, R. G. 141

Berger, A. 153

Bergh, J. 323

Berrino, P. 89

Bjursten, L. M. 173

Blomgren, I. 189, 197, 327

Bohmert, H. 141

Borghouts, M. H. M. 25

Bos, M. Y. 37

Brånemark, P.-I. 207

Bricout, N. 93

Broomé, A. 303

Broström, L.-Å. 289

Bugyi, I. 137

Carù, A. 147

Cerutti, V. 85

Chaglassian, T. 109

Cipollini, T. L. 147

Dahlin, L. B. 279

Danielsen, N. 279

Dioguardi, D. 115

Duchateau, J. 55

Edeling, C. J. 235

Eiken, O. 229

Einarsson, O. J. 331

af Ekenstam, F. 239

Ekerot, L. 219, 225, 285, 293

Engkvist, O. 239, 243, 251

Ericson, L. E. 173

Ferreira, M. C. 133

Fogdestam, I. 319

Fontana, C. 133

Forsby, N. 303

Gabbianelli, G. 133

Galli, A. 89

Gregersen, B. N. 119

Grénman, R. 297

Gumener, R. 61 ter Haar, B. G. A. 37

Hagert, C. G. 207

Hallmans, G. 165

Hammer, H. 137

Hemmy, D. 3

Holmberg, J. 219, 285, 293

Holmström, H. 51, 189, 197, 313

Inoue, K. 31

Irstam, L. 207

Iwahira, Y. 79

Jakobsson, O. P. 323

Jonsson, K. 225

Jousimies-Somer, H. 297

Kaitila, I. 45

Källén, R. 303

Kauer, C. 129

Kjeldsen, H. 119

Koeyers, G. F. 25

Kovachev, D. 109

Lähteenmäki, T. 183

Langeland, N. 161

Lauritzen, C. 201, 327

Lejour, M. 55

Lilja, J. 201, 319, 327

Lossing, C. 313

Lundborg, G. 279

Magnusson, B. 327

Marttinen, E. 45

Marty, F. 61

Maruyama, Y. 79

Massad, M. 307

Massei, A. 41

Matsumoto, K. 31

Medgyesi, S. 235

Meyer, L. 101

Montandon, D. 61

Moser, E. 141

Musharafieh, R. C. 307

Mussinelli, F. 147

Mühlow, A. 303

Nachemson, A. K. 279

Necking, L. E. 225, 229

Nicolai, J.-P. A. 37

Nicolle, F. V. 67

Niechajev, I. 293
Nielsen, I. M. 123

Nordin, U. 259

Oberto, E. 85

Ohlsén, L. 251, 259

Onishi, K. 79

Pascone, M. 115

Perla, A. 85

Pers, M. 123, 331

Petrella, G. 97

Potaznik, A. 55

Quondamcarlo, C. 89

Radek, A. J. 273

Rainero, M. L. 89

Rank, F. 165

Rantala, S.-L. 45

Reichert, H. 125

Ringberg, A. 101

Rintala, A. 45, 297

Rönningen, H. 161

Sälgeback, S. 285

Santi, P. 89

Scrocca, A. 97

Segerström, K. 251

Siuda, S. 141

Snorrason, K. 123, 235

Solheim, L. F. 161

Sonsino, G. 129

Stark, A. 289

Strid, K. G. 207

Suurküla, M. 313

Svartengren, G. 289

Teich-Alasia, S. 85

Tengrup, I. 165

Tessier, P. 3

Theuvenet, W. T. 25

Thomsen, P. 173

Tolhurst, D. E. 75

Vällfors, B. 201

Weinstein, L. P. 109

Wetter, L. 165

Widenfalk, B. 251

Zbrodowski, A. 61

Zellner, P. R. 137 


\title{
A MICROSURGICAL METHOD FOR RECONSTRUCTION OF INTERRUPTED LYMPHATIC PATHWAYS:
}

\author{
Autologous Lymph-vessel Transplantation for Treatment of Lymphedemas
}

\author{
R. G. Baumeister, S. Siuda, H. Bohmert and E. Moser \\ From the Department of Surgery (Head: G. Heberer), and the Department of Radiology (Head: J. Lissner), \\ Division of Nuclear Medicine. University of Munich, Klinikum Grosshadern, München. West Germany
}

\begin{abstract}
Refinements in microsurgery have made it possible to perform causal therapy on lymphedemas due to a local blockade of lymphatic pathways through transplantation of the patient's lymph collectors. End-to-end anastomoses with lymphatics before and after the blockade or crossing to the opposite side are performed under 40 -fold magnification. Between July 1980 and February 198532 patients received this treatment. 23 patients had postmastectomy edema, and 9 patients had unilateral edema of the lower limb (2 primary, 7 secondary edemas). The lasting result was that the volume difference between the affected and the healthy limb decreased to about $65 \%$. Lymphatic scintiscans showed improved lymphatic transport capacity with increasing time from surgery and long patency of the grafts.
\end{abstract}

Key words: Lymphedema, microsurgery, lymph vessels. transplantation, angiology, plastic surgery.

Lymphedemas have been surgically treated in many ways, ranging from resectional methods to lymph draining methods, including lymphovenous shunts $(8,9,14)$. There is no causal therapy for the repair of locally damaged lymph collectors.

Refined microsurgical techniques are comparable to grafting and bypasses in cases of obstructed arteries. Lymphedemas due to local blockade can be treated in this way.

In Europe most lymphedemas are secondary iatrogenic ones, such as postmastectomy edemas. Primary lymphedemas with unilateral atresia in the pelvic region can also be treated with this method.

After animal experiments with lympho-lymphatic anastomoses and lymphatic grafts $(1,3,5,6)$ lymphvessel transplantation in man has been performed since $1980(2,4,7)$.
Transplanted collectors can increase diminished lymphatic transport capacity (10) which may be caused by numeric reduction of lymph-transporting collectors in the region of the blockade. This raises the lymphatic transport-capacity, and causal therapy through direct lymph vessel reconstruction is achieved.

\section{MATERIAL AND METHODS}

Lymphatic grafts are taken from the inner aspect of the thigh. Within the ventro-medial bundle 6-17 superficial lymph collectors can be found (13). In most cases 2 of them are used as grafts and are harvested between the narrowings of the lymphatic system at the leg, the knee and the groin with lengths of up to $30 \mathrm{~cm}$ (Fig. 1). Subcutaneous application of Patent Blue ${ }^{\circledR} \mathrm{V}$ facilitates preparation in the donor region. In postmastectomy edemas, a short longitudinal incision at the upper arm is made and then ascending collectors are sought microscopically, without application of patent bluc. Lymph vessels are found subfascially around the brachial vein and epifascially at the inner aspect of the upper arm.

In longstanding edemas the deep lymph vessels may especially have thickened walls with very small lumens. The superficial ones may be very thin. A short incision is performed at the neck parallel to the lateral border of the sternocleidomastoideus muscle. Deep descending lymphatics, generally thin-walled, can be found there.

A tunnel with a plastic tube is made in the subcutaneous tissue between the two incisions. The grafts are pulled through and the tube is then removed (Fig. 1). With 40-fold magnification lympho-lymphatic anastomoses are performed in the upper arm and the neck using the "tension free anastomosing technique" (5).

The lymph vessels are not turned around the corner stitches. Instead, the vessel ends are allowed to remain lying opposite to one another. The first stitch is made in the part of the vessel that is farthest from the surgeon, and the back wall of the vessel is sutured by simply lifting the 

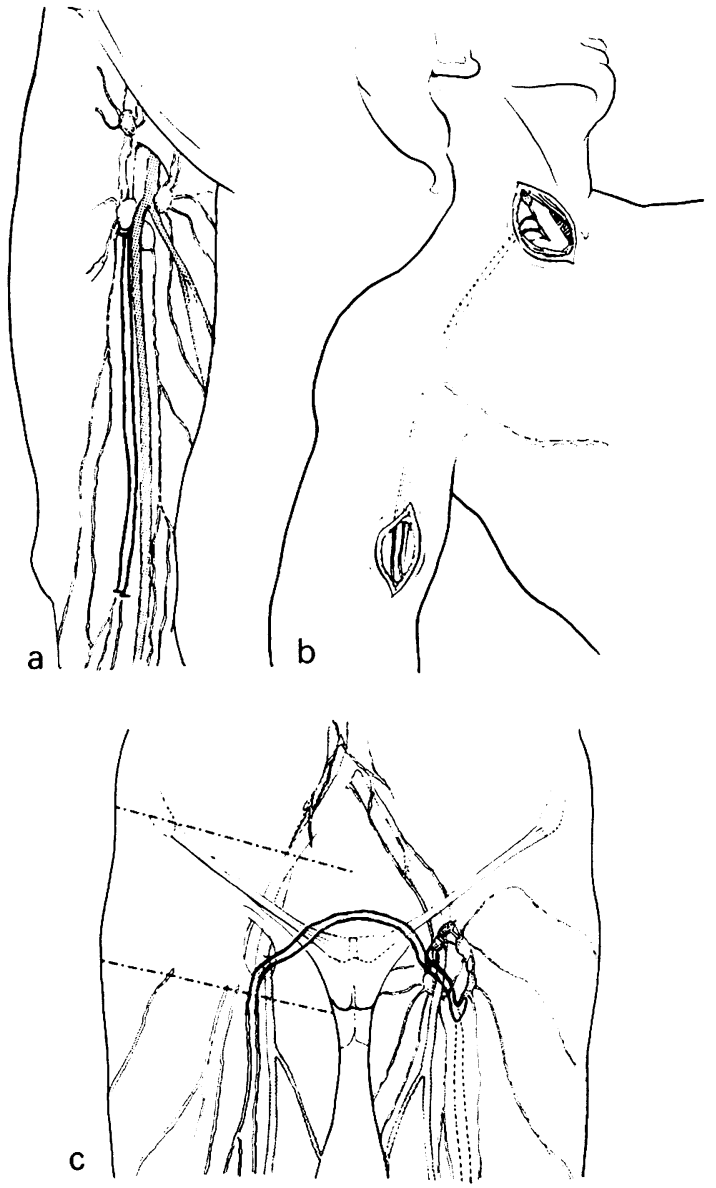

Fig. 1. (a) Harvesting of lymph collectors (dark) of the ventromedial bundle at the thigh. (b) Interposing of transplanted lymph collectors between ascending lymph vessels at the upper arm and descending lymph vessels at the neck in the case of a postmastectomy edema. (c) Transposing of lymphatic grafts via the symphysis in the case of a blockade at the right groin or the pelvic region.

vessel to make room for the needle, without turning. The stitching is knotted on the outside of the vessel.

The corner closest to the surgeon and the front wall are also sutured by single stitches. Generally 6-8 stitches are necessary for the anastomosis. 11-12 $\times 0$ absorbable suture material has given the best results (6).

No clamps are used. In some animal experiments we have seen an obliteration at the site of the pressure. In the case of unilateral edema of the lower leg, the grafts at the donor site remain connected with their lymph nodes at the groin. Ascending collectors are sought on the thigh of the affected limb. A tunnel is made above the symphysis and the transplants are pulled through a tube which is then removed. This allows lymph to flow from the affected side to the lymph nodes at the groin of the opposite leg (Fig. 1).

In the case of localised lymphedema caused by. a peripheral lymphatic blockade at an extremity collectors are
Table I. Patients treated by autologous lymph-vessel transplantation for the treatment of primary and secondary lymphedema

Patients 32

Edema of the arm

Edema of the leg 9 Primary

Iatrogen

Post-traumatic

1

Table II. Patients with postmastectomy edema $n=23$

$\begin{array}{ll}\text { Age } & \\ \text { Mean } & 53(40-70) \text { years } \\ \text { Affected arm } & \\ \text { Right } & 12 \\ \text { Left } & 11\end{array}$

Duration from mastectomy to lymphatic grafting Mean 7 years (17 months -19 years)

Duration from beginning of the edema to lymphatic grafting

Mean 5 years (12 months - 14 years)

Table III. Arm volumes in patients with postmastectomy edemas; preop. versus postop. values compared to the contralateral extremities

Arm volumes at lymph-vessel transplantation

\begin{tabular}{|c|c|c|}
\hline & $n$ & $\mathrm{~cm}^{3}$ \\
\hline Normal & 22 & $1878 \pm 55$ \\
\hline $\begin{array}{l}\text { Preop. } \\
\text { Poston }\end{array}$ & 22 & $3250 \pm 140$ \\
\hline $\begin{array}{l}\text { Postop. } \\
14 \text { days }\end{array}$ & 22 & $2464 \pm 88^{*}$ \\
\hline 72 weeks & 21 & $2486 \pm 126^{*}$ \\
\hline 106 weeks & 21 & $2365 \pm 120^{*}$ \\
\hline
\end{tabular}

${ }^{*} p<0.001$ to preop. values.

sought in front and behind the blockade. Sometimes a direct anastomosis is possible after mobilisation; otherwise short grafts are used to bridge the defects.

Preoperative investigations must clearly exclude blockades due to tumor development or tumor recurrency. Transient edemas are excluded by waiting several months. Conservative treatment should always precede surgery. However, if conservative therapy shows no lasting success without continuous treatment, surgical improvement of lymphatic transporting capacity should not be postponed indefinitely.

The donor leg has to have normal lymphatic transport as proved by lymphatic scintiscans to minimize the risk of a 
Table IV. Behaviour of arm volumes after lymph-vessel transplantation with increasing time from surgery

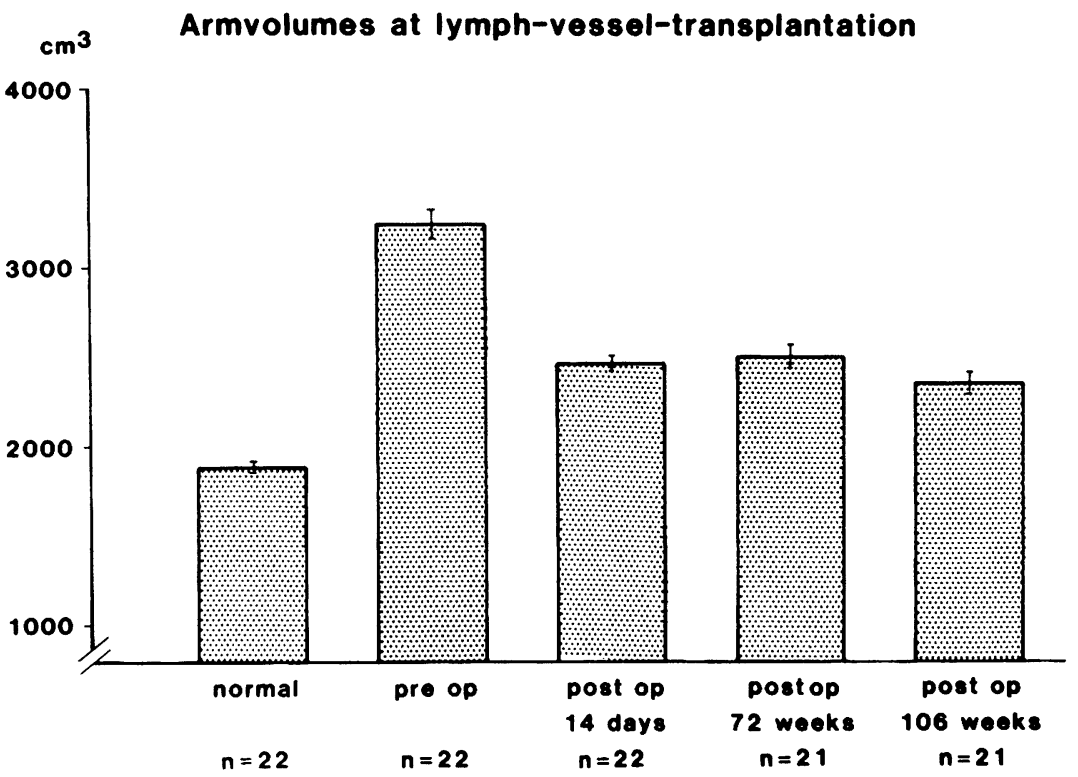

postoperative swelling. In the affected limb the rate of the blockade should be estimated (12) by measuring the transport index.

Lymphatic scintiscans enable us to measure the benefit of the operation and to demonstrate the patency of the collectors. As postoperative management the patients receive low molecular dextrane and antibiotics for one week. As prophylaxis against erysipelas Penicillin (Tardocillin $1200^{\circledR}$ ) is given monthly for 1 year.

Table V. Arm volumes in 11 postmastectomy edemas with a mean time from surgery of 3 years

Arm-volumes 3 years after lymph-vessel-transplantation

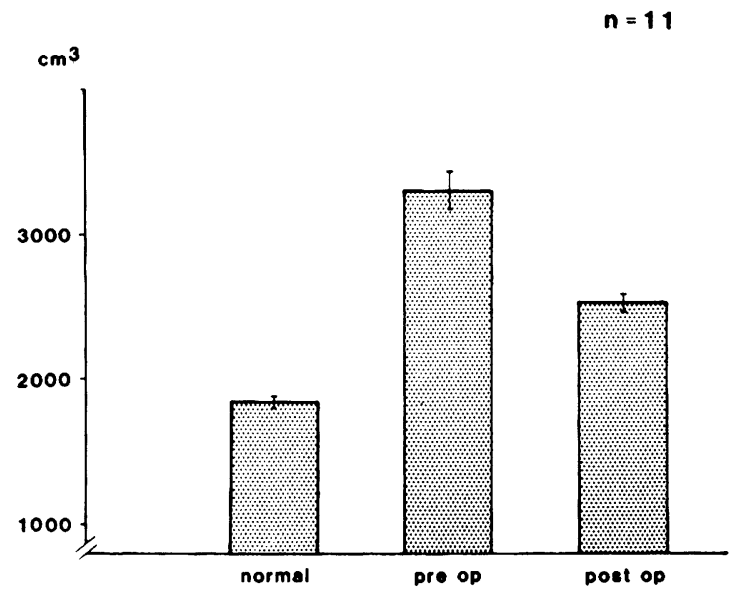

During the approximately 14-day hospital stay the arm is elevated and a light dressing is applied. Elastic stockings are generally worn postoperatively for 6 months.

\section{Indication}

Secondary lymphedemas due to a local blockade of the lymphatic system are most suitable for lymph-vessel transplantations. Postmastectomy edemas, edemas after lymph-node dissection at the groin or wide preparations at the inner aspect of the knee are the most frequent types. Traumas in these regions may also cause edema requiring this treatment. Unilateral primary lymphedemas due to lymphatic hypoplasia in the pelvic region can be treated with lymphvessel transplantation.

\section{RESULTS}

The first lymph-vessel transplantation in man was performed in June 1980. By February 198532 patients were treated. Most patients (23) suffered from postmastectomy edema. Two of the nine patients with edema of the leg had primary edema, six had secondary iatrogenic edema and 1 had secondary posttraumatic edema (Table I). The mean age of the patients with postmastectomy edemas was 53 , the youngest was 40 and the oldest patient 70 years old. There was no preference for one side. The mean time between mastectomy and lymphatic grafting was 7 years, the shortest time 17 months, the longest 19 years. The time between the occurrence of the edema and surgery was a mean of 5 years. 12 months 
Table VI. Decrease of lymphatic transport index, i.e. elevation of lymphatic transport capacity after lymphvessel transplantation

Lymphatic scintiscan in postmastectomy edema $(n=10)$

Transport-index

\begin{tabular}{|c|c|c|}
\hline Preop. & $\begin{array}{l}\text { Postop. } \\
\text { (14 days) }\end{array}$ & $\begin{array}{l}\text { Postop. } \\
\text { ( } 21 \text { months) }\end{array}$ \\
\hline 35.4 & 32.6 & 19.8 \\
\hline
\end{tabular}

was the shortest time, 14 years the longest (Table II).

In 22 postmastectomy-edemas pre- and postoperative values of volumes are comparable to the volumes of the contralateral normal extremity. The results in mean volumes and standard deviations (Table III) show a significant decrease in volume even long after the patient's return to normal life. The overall decrease of volume difference remained at about $65 \%$ (Table IV).

In 11 patients a mean observation period of 3 years after the operation was reached. A significant reduction can also be seen after this period (Table V).

As an independent and objective measurement of the lymphatic outflow, lymphatic scintiscans show a significant reduction of the transporting index, that is an improvement of the lymphatic transport capacity, after a mean period of 21 months (Table II). The data indicate that lymphatic flow continues to improve with time after the surgery.

In seven patients with edemas of the leg volume measurements have been performed (11). The data also show a marked decrease in volume after lymphatic grafting which lasted after the patient returned to normal life. In the lower extremity, however, it is more difficult to maintain the postoperative results than in the upper extremity (Table VII).

We saw a complication of erysipelas in 2 of our first patients without penicillin prophylaxis. One patient had swelling in the lower leg. There were clinical signs of deep venous thrombosis, but the patient did not permit examination by phlebography or lymphatic scintiscan.

The clinical example shows a 42-year-old patient: The lymph-vessel transplantation took place 10 years after mastectomy, axillary lymph-node dissection and radiation and 3 years after development of a marked lymphedema of the right arm (Fig. 2). 2 years after autologous lymph-vessel transplantation a constant reduction of the arm volume was achieved (Fig. 2).

The example of a lymphatic scintiscan shows a 31year-old patient, suffering from carcinoma of the bladder with a blockade of the left pelvic lymphatic pathway after lymph-node dissection.

In the preoperative scintiscans injections were performed on both lower limbs. On the right leg a normal outflow could be seen. On the left leg a stoppage before the groin was detected (Fig. 3).

$21 / 2$ years after lymph-vessel transplantation injection only on the left leg was performed. The lymph flows via the transplanted collectors from the affected left leg to the right groin and from there to the right pelvic lymph nodes. The stoppage before the left groin is released and the normal collectors are visualized again. Thus patency of the transplants and functional improvement of lymphatic transport in the affected limb can be demonstrated by objective measurements (Fig. 3).

\section{DISCUSSION}

The results show that a direct reconstruction of main lymph collectors can be used to treat lymphedemas due to a local blockade of the lymphatic system. The effect is not transient, but rather lymphatic scintigraphies show an improvement of the lymphatic flow with increasing time from the lymphatic grafting.

A reduction of the affected extremity to normal size is unlikely in cases with a large amount of newly connective tissue in the edematous extremity.

After successful lymph-vessel transplantation, however, the patients, especially in postmastectomy

Table VII. Volumes of the leg in cases of autologous lymp-vessel transplantation/transposition in lymphedemas of the leg

\begin{tabular}{|c|c|c|c|c|}
\hline & Normal & Preop. & $\begin{array}{l}\text { Postop. } \\
\text { (14 days) }\end{array}$ & Postop. \\
\hline B. H. & 8618 & 11552 & 9563 & 9872 (23 weeks) \\
\hline S. M. & 7741 & 10972 & 8671 & 8024 ( 109 weeks) \\
\hline S. S. & 5233 & 6323 & 5178 & 5387 (28 weeks) \\
\hline S. G. & 7948 & 10029 & 8598 & 8762 (68 weeks) \\
\hline M. J. & 8816 & 9616 & 8411 & 9367 (20 weeks) \\
\hline M. D. & 7034 & 7363 & 6338 & 6758 (59 weeks) \\
\hline S. M. & 5506 & 8364 & 6390 & 6608 (26 weeks) \\
\hline
\end{tabular}




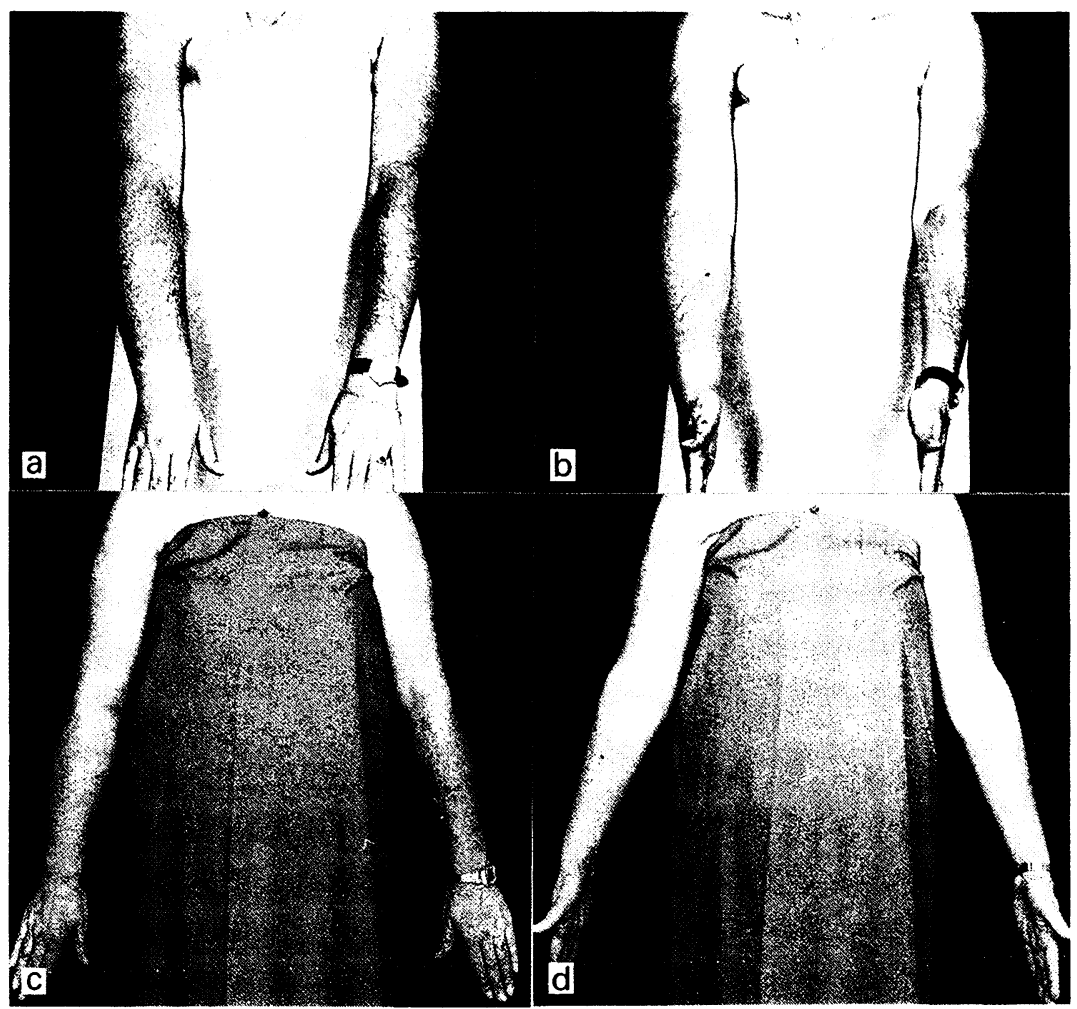

Fig. 2. $(a, b)$ 42-year-old patient with a postmastectomy edema of the right arm. (c, d) Patient 2 years after autologous lymph-vessel transplantation.
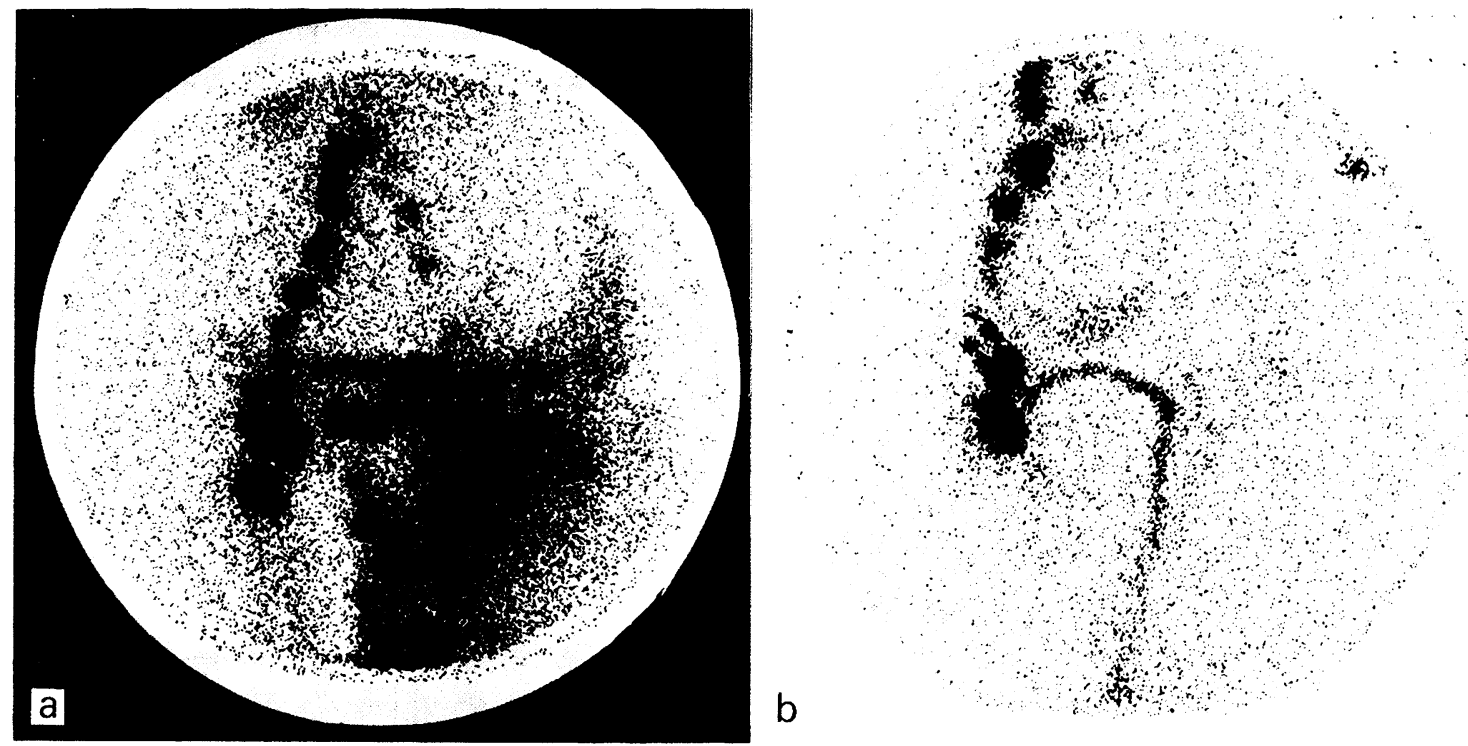

Fig. 3. (a) Lymphatic scintiscan of a 31-year-old patient with lymphatic blockade at the left pelvic region after lymphnode dissection. Injections in both feet, normal transport on the right side, stoppage at the left leg. (b) $21 / 2$ years after lymphvessel transplantation via the symphysis. Injection only at the left foot; patent transplants; lymphatic outflow through the transplants via the symphysis to the right groin and the pelvic lymph nodes; release of the stoppage. 
edemas, are no longer bothered by markedly swollen hands and forearms or by having to wear elastic stockings. Using the method of lymphatic grafting instead of lymphovenous anastomoses does away with problems of pressure differences between lymph vessels and veins (15) and with the higher coagulability in the blood than in the lymph (16). The restoration takes place within the lymphatic system. The best results can be achieved when the transport capacity exceeds the lymphatic load of the edematous limb.

\section{REFERENCES}

1. Baumeister RGH, Seifert J, Wiebecke B. Transplantation of lymph vessels on rats as well as first applications on the experimental lymphedema of the dog. Eur Surg Res 1980; 12, Suppl. 2: 7-8.

2. Baumeister RGH, Seifert J, Hahn D. Autotransplantation of lymphatic vessels. Lancet 1981; Jan. 17: 147.

3. Baumeister, RGH, Seifert D, Wiebecke B. Experimentelle Grundlagen der Lymphgefäßtransplantation. Langenbecks Arch Chir 1981; Suppl. 77-81.

4. Baumeister RGH, Seifert J, Wiebecke B, Hahn D. Experimental basis and first application of clinical lymphvessel transplantation of secondary lymphedema. World J Surg 1981; 5: 401-407.

5. Baumeister RGH, Seifert J, Wiebecke B. Homologous and autologous experimental lymph-vessel transplantation initial experience. Int J Microsurg 1981; 3: 19-24.

6. Baumeister RGH, Seifert J, Wiebecke B. Untersuchungen zum Verhalten von resorbierbarem und nichtresorbierbarem Nahtmaterial bei der Lymphgefäßnaht. Handchirurgie 1982; 14: 87-91.

7. Baumeister RGH. Mikrochirurgie des Lymphgefäßsystems. Chirurg, Springer Verlag 1983, 54: 374-378.

8. Brunner U. Das Lymphoedem der unteren Extremitäten. Huber, Bern 1969.

9. Clodius L. Lymphedema. Thieme, Stuttgart 1977.

10. Földi M. Physiologie des Lymphegefäßsystems. Angiologica $1971 ; 8: 212$.

11. Kuhnke E. Volumenbestimmung aus Umfangsmessungen. Folia Angiol 1976; 24: 228-232.

12. Kleinhans E, Baumeister RGH, Hahn D, Siuda S, Büll U, Moser E. Evaluation of transport kinetics in lymphoscintigraphy: Follow-up study in patients with transplanted lymphatic vessels. Eur J Nucl Med 1985; 10: 349-352.

13. Kubik S. Zur klinischen Anatomie des Lymphsystems. Verh Anat Ges 1975; 69: 109-116.

14. O'Brien BM, Shafiroff BB. Microlymphatico venous and resectional surgery in obstructive lymphedema. World J Surg 1979; 3: 3-15.

15. Yamada Y. The study of lymphatic venous anastomosis in lymphedema. Nagoya J Med Sci 1969; 32: 1-21.

16. Yoffey, JM, Courtice FC. Lymphatics, lymph and the lymphomyeloid complex. 2nd ed. Academic Press. New York, London 1970. 